\title{
Desentralisasi Asimetris Kewenangan Provinsi Kepulauan dalam Pengelolaan Sumber Daya Alam untuk Mewujudkan Kesejahteraan Masyarakat
}

\author{
Amiruddin Umasangaji \\ Dosen Fakultas Hukum Universitas Khairun, Email: amirudin.umasangaji@gmail.com
}

\author{
Ahmad Mufti \\ Dosen Fakultas Hukum Universitas Khairun. Email: ahmad mufti.unkhair@gmail.com
}

\section{Sri Indriyani Umra}

Dosen Fakultas Hukum Universitas Khairun. Email: indrysiu19@gmail.com

\begin{abstract}
The research entitled Asymmetric Decentralization of the Authority of Archipelago Provinces in Natural Resources Management to Realize Community Welfare aims to (1) determine the meaning and urgency of implementing the concept of asymmetric decentralization in regulating the authority of archipelagic provinces; and (2) analyze how the authority of the archipelagic provinces in the management of natural resources can create public welfare. This research is a normative legal research (juridical normative) using approaches including: a statute approach, a conceptual approach, and a historical approach. This research uses the main theory "welfare law state theory" to analyze the achievement of the goal of legal development, namely the welfare of the community. In order to analyze the existing problems, several relevant concepts were also used, including: (1) the concept of asymmetric decentralization and regional autonomy; and (2) the concept of an archipelagic state and archipelagic province that is specifically focused on the formulation of the norms of regional government authority in provinces characterized by islands.
\end{abstract}

Keywords: Asymmetric Decentralization; Islands; Natural Resources

\section{PENDAHULUAN}

Undang-Undang Dasar Negara Republik Indonesia Tahun 1945 (selanjutnya disebut UUD NRI Tahun 1945) memberikan penegasan wilayah negara yakni negara kepulauan yang berciri nusantara pada Pasal 25A dengan potensi keanekaragaman sumber daya hayati diwilayah pesisir dan laut serta sebaran daerah berkarakter pesisir yang terletak hampir pada 34 provinsi.

Politik hukum kewenangan provinsi kepulauan dirumuskan melalui UU Nomor 23 Tahun 2014 berkaitan dengan pengelolaan sumber daya alam yang ada dilaut meliputi 5(lima) kewenangan yang bersifat multi regulated, tidak terpisahkan dengan pengaturan dalam UU sektoral lainnya sehingga memerlukan sinkronisasi dan harmonisasi pengaturan, namun teridentifikasi adanya ketidaklengkapan norma (uncompleted norm) dan konflik norma (conflict norm) dalam UU sektoral yang mempengaruhi pencapaian tujuan kesejahteraan masyarakat terutama pada provinsi kepulauan. Adanya inisiasi 
pemerintah daerah provinsi kepulauan di Indonesia serta masuknya RUU Daerah Kepulauan dan RUU Cipta Karya dalam Prolegnas 2020-2024 memerlukan kajian mendalam mengurai makna dan urgensi produk hukum yang akan dibuat terhadap kewenangan provinsi kepulauan.

Berlandaskan pada uraian diatas, maka penelitian ini dimaksudkan untuk menganalisis makna dan urgensi pengaturan kewenangan provinsi kepulauan dalam pengelolaan sumber daya alam yang selaras dengan perwujudan tujuan pembangunan nasional, dengan lingkup permasalahan, yaitu Apa makna dan urgensi penerapan konsep desentralisasi asimetris dalam pengaturan kewenangan provinsi kepulauan? dan Bagaimana pengaturan kewenangan provinsi kepulauan dalam pengelolaan sumber daya alam yang dapat mewujudkan kesejahteraan masyarakat?

\section{METODE PENELITIAN}

Penelitian "Desentralisasi Asimetris Kewenangan Provinsi Kepulauan Dalam Pengelolaan Sumber Daya Alam Untuk Mewujudkan Kesejahteraan Masyarakat" merupakan penelitian hukum normatif. Dalam perspektif Peter Mahmud Marzuki menyatakan bahwa penelitian hukum adalah proses untuk menemukan aturan hukum, prinsip-prinsip hukum maupun doktri-doktrin hukum guna menjawab isu hukum yang dihadapi. Penelitian hukum dilakukan untuk menghasilkan argumentasi, teori atau konsep baru sebagai preskripsi dalam menyelesaikan masalah yang dihadapi, sehingga jawaban yang diharapkan didalam penelitian hukum adalah right, appropriate, inappropriate atau wrong. ${ }^{1} \quad$ Penelitian hukum ini dimaksudkan untuk menganalisa urgensi pengakuan dan perlindungan hak masyarakat hukum adat pada aspek penataan ruang dari sisi filosofis, yuridis serta politik hukum. Pendekatan yang digunakan dalam penelitian ini antara lain pendekatan undang-undang (statute approach), pendekatan konseptual (conceptual approach), dan pendekatan historis (historical approach).Alur penelitian normatif meliputi identifikasi isu hukum, inventarisasi bahan hukum, pengumpulan bahan hukum (primer, sekunder, tersier) serta analisis bahan hukum. Pengumpulan data merupakan prosedur menggunakan instrumen penelitian kepustakaan. Untuk memperoleh data yang valid dan reliabel, dilakukan inventarisasi bahan hukum yang berkaitan dengan fokus penelitian yakni kewenangan pemerintah daerah provinsi kepulauan, pengelolaan sumber daya alam dan kesejahteraan masyarakat berdasarkan hierarkhi bahan hukum yang telah diidentifikasi. Hasil inventarisasi studi kepustakaan dianalisis dengan menggunakan tehnik preskriptif analitik dimana data disusun selanjutnya direduksi melalui abstraksi, diinterpretasi dan dianalisa dengan menggunakan analisa kritis (critical analysys) terhadap bahan hukum dan bersifat kualitatif dengan tehnik interpretasi hukum. Pengolahan data penelitian ini diawali dengan mengelompokan data dan informasberdasarkan kategori perlindungan hukum, hak masyarakat hukum adat dan kebijakan penataan ruang, selanjutnya dilakukan interpretasi/analisis keseluruhan aspek yang menjadi pokok permasalahan penelitian secara induktif sehingga memperoleh gambaran utuh.

\section{ANALISIS}

\section{A. Makna dan Urgensi Penerapan Konsep Desentralisasi Asimetris Dalam Pengaturan Kewenangan Provinsi Kepulauan}

\footnotetext{
${ }^{1}$ Peter Mahmud, Penelitian Hukum, (Jakarta: Kencana, Prenada Media Group, 2007), hlm. 35
} 
Negara kesatuan merupakan bentuk negara yang palin tepat untuk menjadi wadah ide persatuan. Istilah negara kesatuan ini secara tegas dinyatakan dalam UUD 1945 Pasal 1 ayat (1) sebagai suatu negara kesatuan yang berbentuk republic. Di dalam negara kesatuan, pemegang tampuk kekuasaan tertinggi atas segenap urusan negara di tangan pemerintah puaat. Namun, tidak berarti bahwa kebijakan yang diterapkan di dalam negara kesatuan harus diseragamkan (uniform). Dalam hal ini, negara juga mengakui keragaman yang dan dijamin dalam Pasal 18 UUD 1945. Sebagaimana dikemukakan oleh The Liang Gie, bahwa tiap daerah mempunyai historis dan sifat khusus yang berlainan daripada riwayat dan sifat daerah lain. Sehubungan dengan hal tersebut, pemerintah harus menjauhkan segala urusan yang bermaksud akan menguniformisir seluruh daerah menurut satu model. ${ }^{2}$ Berdasarkan dari latar belakang NKRI yang ditetapkan sejak awal berdiri sebagai negara kesatuan, dipandang paling tepat untuk mewadahi persatuan dari suatu bangsa yang majemuk yang terdiri dari keragaman suku bangsa, agama, dan budaya. Keragaman ini merupakan kekayaan yang harus dipersatukan (united) tetpi tidak untuk diseragamkan (uniformed). Oleh karena itu, prinsip persatuan tidak boleh diidentikkan dengan kesatuan. Maksudnya bentuk negara kita adalah negara kesatuan (unitary state), sedangkan persatuan Indonesia adalah prinsip dasar bernegara yang harus dibangun atas dasar persatuan (unity), bukan kesatuan (uniformity). ${ }^{3}$

Desentralisasi asimetris (asymmetrical decentralisation) adalah pemberlakuan/transfer kewenangan khusus yang hanya diberikan pada daerahdaerah tertentu dalam suatu negara, yang dianggap sebagai alternatif untuk menyelesaikan permasalahan hubungan antara pemerintah pusat dan pemerintah daerah, dalam konteks Indonesia dalam rangka menjaga eksistensi daerah dalam NKRI. Desentralisasi asimetris mencakup desentralisasi politik, ekonomi, fiskal, dan administrasi, namun tidak harus seragam untuk semua wilayah negara, dengan mempertimbangkan kekhususan masing-masing daerah. Penerapan kebijakan desentralisasi asimetris merupakan sebuah manifestasi dari usaha pemberlakuan keistimewaan. Konsep tersebut sebenarnya sudah dijalankan dalam praktik ketatanegaraan Republik Indonesia, yaitu dengan adanya beberapa daerah yang berstatus istimewa/berotonomi khusus seperti Provinsi Papua \& Papua Barat, Provinsi Aceh, Provinsi Daerah Khusus Ibukota Jakarta, dan Provinsi Daerah Istimewa Yogyakarta. Kelima provinsi ini secara legal formal sudah memperoleh pengakuan dari negara. Inti desentralisasi asimetris adalah terbukanya ruang gerak implementasi dan kreativitas provinsi dalam pelaksanaan pemerintahan daerah di luar ketentuan umum dan khusus yang diatur dalam Undang-Undang Nomor 23 Tahun 2014 tentang Pemerintahan Daerah, ataupun peraturan perundang-undangan lainnya. ${ }^{4}$ Selanjutnya Jimly menegaskan bahwa ketentuan Pasal 18, Pasal 18A dan 18B UUD 1945 telah mengubah format bentuk negara kesatuan yang kaku kepada bentuk negara kesatuan dinamis. Kerangka pikir negara kesatuan republik Indonesia dalam melihat konsep desentaralisasi asimetris,memiliki alasan diantaranya: ${ }^{5}$

\footnotetext{
${ }^{2}$ Nyimas Latifah Letty Azis dkk,Model Desentralisasi Asimetris Dalam NKRI,Jakarta,Yayasan Pustaka Obor Indonesia,2020,hlm 16

${ }^{3}$ Ibid.,hlm 17

4 Gunawan A. Tauda,"Desain Desentralisasi Asimetris Dalam Sistem Ketatanegaraan Indonesia",Jurnal Admnistrative Law dan Governance Law,Edisi No 4 Vol. I,2018,hlm 415

${ }^{5}$ Ibid.,
} 
Pertama, dimungkinkan dilakukannya pengaturan yang sifatnya federalistik dalam hubungan pusat dan daerah. Kedua, dalam dinamika hubungan tersebut dimungkinkan pula dikembangkannya kebijakan otonomi yang pluralis dimana setiap daerah dapat menerapkan pola otonomi yang berbeda sebagaimana otsus di Aceh, Papua, Papua Barat, dan istimewa di DIY. Pola otonomi yang berbeda untuk beberapa daerah tersebut yang dikenal dengan kebijakan desentralisasi asimetris. ${ }^{6}$ Pengembangan desentralisasi asimetris di Indonesia perlu memperhatikan kondisi-kondisi yang diperlukan bagi keberhasilan desantralisasi asimetris itu sendiri, dan berbagai konteks kekinian yang dikembangkan adalah desantralisasi asimetris dalam negara kesatuan pilihan negara kesatuan telah jelas termuat dalam konstitusi dan masih menjadi konsensu politik. Walaupun konsep negara kesatuan mengalami dinamika dan penyesuaian sesuai dengan tantangan yang dihadapi, desentralisasi asimetris dalam negara kesatuan memiliki ciri yang berbeda dengan desentralisasi asimetris dalam negara yang menganut system federal. Pada umumnya desentralisasi di negara kesatuan hanya terjadi dalam kewenangan eksekutif, bukan dalam kewenangan legislasi dan yudisial. Sedangkan desentralisasi di negara federal mencakup semua cabang pemerintahan, karenanya provinsi atau negara bagian memiliki lembaga legislative dan yudisial. Desentarlisasi dalam negara kesatuan umunya lebih banyak terjadi pada pemerintah kabupaten/kota. Sedangkan desentralisasi dala negara federal ialah desentralisasi pada umumnya adalah creatures dari negara bagian karena itu mereka seringkali tidak menerima kewenangan yang signifikan.

Pilihan mengembangkan Indonesia menjadi negara kesatuan yang desentralistik menurut adanya konstruksi hubungan pusat dan daerah yang berbeda dengan konstruksi dalam system federal. Praktik di negara kesatuan, daerah (bisa provinsi atau kabupaten/kota) umumnya dibentuk oleh negara (pusat). Oleh karena itu, daerah memperoleh kewenangan dari negara, bukan sebaliknya. Negara melalui UndangUndang dapat membentuk dan membubarkan daerah, melimpahkan atau menarik kembali kewenangan dan fungsi yang dilimpahkan ke daerah. Kewenangan yang diberikan kepada pemerintahan daerah adalah kewenangan eksekutif yang dimiliki oleh presiden. UUD 1945 memberi kekuasaan pemerintahan tertinggi pada presiden. Presiden sebagai pemegang kekuasaan pemerintahan tertinggi harus mempertanggungjawabkan penyelenggaraan pemerintahan nasioanl, termasuk yang dilakukan oleh pemerintahan daerah. Oleh karena itu, presiden memiliki kewenangan untuk melakukan pengawasan terhadap penyelenggaraan pemerintahan daerah, baik yang dilakukan oleh provinsi ataupun kabupaten/kota.

Kedua, sebagaimana dinyatakan dalam konstitusi (UUD 1945) Pasal 18 dan 18A), indoensia menganut system pemerintahan dengan susunan ganda (multi-riers government). Walaupun desentralisasi pemerintahan dilakukan pada semua susunan pemerintahan, namun orientasinya lebih banyak kepada kabupaten/kota. Implikasinya, prinsip subsidiaritas menjadi pertimbangan utama dalam melakukan pembagian urusan pemerintahan, utamanya ketika prinsip tersebut berbenturan dengan kriteria lainnya, misalnya efisiensi. Pertimbangan pembagian urusan kepada pemda karena pemda yang paling dekat dengan warga, dan paling tahu tentang kebutuhan warganya sehingga mudah dikontrol oleh warga, dan memudahkan warga untuk terlibat dalam

${ }^{6}$ Tim tidak memasukkan DKI Jakarta dalam Penyusunan model desentralisasi asimetris karena pertama, DKI Jakarta tidak bisa diterapkan di daerah desentralisasi asimetris lainnya di Indonesia, Status DKI sebagai pusat pemerintahan dan ibukota negara sudah given dan bukan daerah otonom; 
penyelenggaraannya. Pilihan ini diharapkan mampu mempercepat terwujudnya democratic geovernance pada tingkat lokal. Kondisi dalam negara kesatuan yang memiliki susunan ganda, secara hierarkis provinsi dengan kabupaten/kota tidak memiliki hubungan langsung. Tetapi secara fungsional hubungan hierarkis antara keduanya sulit dihindari. Bahkan, dalam manajemen pemerintahan sehari-hari, hubungan interdependi dan interlasi antar pemerintahan kabupaten/kota adalah kensicayaan. Secara fungsional keberadaan provinsi diperlukan untuk memfasilitasi manajemen pemerintahan antar kabupaten/kota agar terjadi koherensi,sinergi dan terintegrasi dengan baik. Apalagi ketika provinsi juga diperlakukan sebagai wilayah administrative, dimana kepala daerahnya diberi tugas sebagai wakil pemerintah pusat di daerah, maka hubungan hirarkis fungsional antara provinsi dan kabupaten/kota tidak dapat dihindari. Namun, pada praktiknya fungsi gubernur sebagai wakil pemerintah pusat di daerah masih belum menjalankan tugasnya dengan efektif, khususnya dalam pengelolaan dana otonomi khusus atau istimewa.

Ketiga, walaupun tidak diatur dalam konstitusi, realitas yang ada menunjukkan bahwa Indonesia menganut desentralisasi territorial dan fungsional. Selama ini desentralisasi territorial sangat dominan sehingga cebderung memonopoli konsep desentralisasi. Pengembangan kawasan khusus Batam dapat dapat menjadi contoh terjadinya desentralisasi fungsional, dimana pemerintah membentuk lembaga di daerah untuk mejalankan fungsi khusus tertentu. Munculnya masalah-masalah strategis terkait dengan kawasan perbatasan, konservasi, dan unggulan ekonomi turut mendorong perlunya Indonesia mengembangkan konsep desentralisasi fungsional.

Keempat, keberhasilan desentralisasi membutuhkan adanya konsistensi dalam keseluruhan aspek kebijakan dan imolementasinya. Pada arah kebijakan, konsistensi diperlukan antarperaturan perundang-undangan yang mengatur tentang penyelenggaraa pemerintahan dengan peraturan perundang-undangan yang mengatur kegiatan-kegiatan kementerian dan lembaga. Undang-undang tentang pemerintahan daerah harus menjadi arah kebijakan yang meniwai dan menjadi pedoman bagi pembentukan UU sektoral. Ketidakharmoniam antara UU tentang penyelenggaraan pemerintahan daerah dengan UU sektoral dapat menciptakan kebinggungan aktor-aktor di pusat dan daerah. Sebagaimana pengalaman di negara-negara lainnya, ketidakharmonisan UU bukan hanya akan menimbulkan kekaburan terhadap substansi perundangan tetapi juga akan mempersulit pelaksanaan desentralisasi itu sendiri. Kekaburan dalam isi kebijakan akan mendorong munculnya salah pemahaman dan distorsi kebijakamn yang tidak perlu dan dapat menjauhkan kebijakan dari nilai yang akan diwujudkannya.

Kelima, pengembangan desentralisasi sebagaimana terjadi pada negara-negara lainnya membutuhkan ruang politik yang lebih luas oleh warga yang terlibat dalan proses politik di local. Desentralisasi harus dilakukan secara bersama-sama demokratisasi pada tingkat lokal sehingga warga dapat terlibat dalam pengambilan keputusan dan ikut mengontrol jalannya penyelenggaraan pemerintahan. Implikasinya, desentralisasi hanya akan berhasil jika diikuti dengan pemberdayaan lembaga sipil di daerah-daerah sehingga efektivitas control politik di daerah menjadi semakin efektif. Tanpa penguatan lembaga perwakilan rakyat dan masyarakat sipil di daerah, desentralisasi hanya akan melahirkan elite captures dalam proses penyelenggaraan pemerintahan di daerah, yang merugikan kepentingan warga dam pemangku kepentingan yang luas. 
Menurut G. Shabbir Cheema dan D. A. Rondineli yang dikutip oleh Ni'matul Huda bahwa dalam tiga dasawarsa (1970-1990-an) pemerintah di negaranegara berkembang telah berupaya mengimplementasikan bermacam kebijakan desentralisasi. Sebagian memiliki lingkup yang menyeluruh dan dirancang untuk mengalihkan perencanaan pembangunan dan pertanggungjawaban pengelolaan kepada unit-unit pemerintahan daerah. Sebagian lain dipahami secara lebih sempit mereka hanya menyebarkan atau merelokasikan tugas-tugas pemerintahan di antara unit-unit pemerintahan daerah. Di sebagian besar negara, kebijakan desentralisasi mempunyai empat bentuk. Pemerintah di negara-negara seperti India, Sudan, dan Tanzania berupaya menyerahkan atau mendelegasikan kuasa pembagian pengambil keputusan kepeda pemerintah daerah atau unit-unit pemerintahan. ${ }^{7}$ Pemerintah lain seperti Brazil, Argentina, Venezuela, dan Meksiko memberikan fungsi perencanaan dan pengelolaan tertentu kepada organisasiorganisasi semi otonom. Hampir semua pemerintahan di Afrika Timur, Utara, dan Asia Selatan mendistribusikan fungsi pembangunan kepada pemerintah provinsi atau distrik. Desentralisasi dibeberapa negara berkembang dilaksanakan dengan metode debirokratisasi. Ini mengindikasikan fungsi-fungsi yang sebelumnya diemban oleh pemerintah diserahkan kepada organisasi-organisasi mandiri atau swasta. Konsep desentralisasi tumbuh dan berkembang seiring dengan tuntutan dan kebutuhan negara demokrasi sejak lama. Menurut Syarif Hidayat dan Benyamin Hosein konsep ini baru banyak diperdebatkan khususnya di negara-negara yang sedang berkembang pada Tahun 1950-an. Pada periode ini dapat dikatakan sebagai gelombang pertama konsep desentralisasi telah mendapat perhatian perhatian khusus dan telah diartikulasikan sebagai konsep yang paling relevan untuk memperkuat dan memberdayakan penyelenggaraannya pemerintahan lokal. Jika dilihat gelombang kedua gerakan desentralisasi, utamanya di negara-negara sedang berkembang adalah pada akhir tahun 1970-an. ${ }^{8}$ Desentralisasi juga seringkali diinterpretasikan sebagai antitesa dari sentralisasi. Antara dua kutub itu dalam perkembangannya tidak jarang diletakkan pada kutub yang saling berlawanan, seharusnya di dalam negara kesatuan di samping keliru untuk mempertentangkan keduanya antaranya keduanya juga tidak bisa ditiadakan sama sekali. Artinya kedua konsep tersebut menurut Lukman Hakim teori tersebut saling melengkapi dan membutuhkan dalam kerangka ideal sebagai sendi negara demokratis. Arti penting desentralisasi esensinya agar persoalan kompleks yang dilatarbelakangi oleh berbagai faktor heterogenis dan kekhususan daerah yang melingkupi seperti budaya, agama, adat istiadat, dan luas wilayah yang jika ditangani semuanya oleh pemerintah pusat merupakan hal yang tidak mungkin karena keterbatasan dan kekurangan hampir di semua aspek. ${ }^{9}$

Dalam hal ini Tartlon membagi konsep desentralisasi asimetris menjadi dua jenis yakni asymmetrical federation ialah asimetri de jure dan asimetri de facto dan asimetri de facto yang ditandai dengan perbedaan pada tingkat otonomi. Istilah asimetri de jure mengacu pada kondisi dimana terdapat penegasan praktik asimetrisme dalam konstitusi. Artinya dalam konstitusi yang sah sudah ditekankan bahwa terdapa unit-unit konstituen yang diperlakukan berbeda di bawah hukum yang sudah ditetapkan. Dalam federasi asimetri de jure, kebijakan dan penentuan perlakukan asimetri kepada masing-masing daerah ditentukan oleh beberapa syarat yang ditetapkan pusat. Adapun istilah federasi

\footnotetext{
${ }_{8}^{7}$ Ni'matul Huda,Desentralisasi Asimeteris Dalam NKRI,Bandung,Nusa Media,2014,hlm 31

${ }^{8}$ Ibid., hlm 35

${ }^{9}$ Ibid,
} 
asimetri de facto mengacu pada perbedaan praktek nyata atau hubungan antar daerah yang muncul karena keadaan sosial, budaya dan ekonomi. Pada pengaplikasiannya federasi asimteris de facto tidak ada keterjaminan hukum standar yang relevan melainkan pada praktiknya sudah lazim dan diterima. ${ }^{10}$ Dalam penelitian yang dilakukan oleh JPP Fisipol UGM (JPP-UGM 2010) menunjukkan setidaknya terdapat lima alasan mengapa desentralisasi asimetris harus dilakukan di Indonesia. ${ }^{11}$

Pertama, alasan konflik dan tuntutan separatisme. Tidak dapat dipungkiri, dua daerah (tiga Provinsi) yaitu Provinsi Aceh, Provinsi Papua dan Provinsi Papua Barat mendapatkan perlakuan khusus dalam bentuk otonomi khusus karena konflik antara kedua daerah tersebut dengan pemerintah nasional yang antara lain karena perebutan sumber daya. Jika diringkas, otsus untuk Aceh dan Papua secara prinsipil terdiri dari: Pertama, dana Otonomi Khusus sebagai kompensasi ketiga provinsi masih dapat bergabung di Republik Indonesia. Kedua, pengakuan terhadap identitas lokal yang terwujud dalam institusi politik. Di Aceh proses ini ditandai dengan adanya lembaga baru yang merepresentasikan adat dan agama. Di Papua, wewenang diberikan kepada adat dan gereja. Ketiga, pengakuan terhadap simbol-simbol lokal seperti bendera, bahasa dls. Keempat, partai politik lokal. Aceh memanfaatkan momentum partai lokal dengan tumbuhnya partai lokal dan memenangkan pemilu, sedangkan di Papua belum ada walaupun ruang untuk hal tersebut telah ada. Kelima, adanya afirmatif action untuk menjadi pemimpin lokal. Di Aceh wujudnya dengan dapat membaca Al Quran, di Papua pemimpinnya harus orang asli papua yang disyahkan oleh Majelis Rakyat Papua. Keenam dan mungkin paling penting, pengaturan terkait sumber daya. Selain dana otsus yang jumlahnya sangat besar, pengelolaah sumberdaya daerah adalah isu yang spesifik. Aceh memiliki beberapa kekhususan spesifik terkait dengan pengelolaan sumber daya, misalnya pertanahan, hutan dan eksploitasi minyak. Karena peliknya urusan sumber daya ini, Pemerintah belum diserahkan ke Aceh dalam bentuk regulasi pendukung misalnya Peraturan Pemerintah sesuai batas waktu yang tertera dalam UU.

Kedua, alasan ibukota negara. Perlakuan khusus ini hanya diberikan untuk Provinsi DKI. Mengingat DKI yang wilayahnya terjangkau dengan infrastuktur terbaik di negeri ini, perlakuan khusus diwujudkan dalam ketiadaan pemilukada untuk Bupati/Walikota dan tidak ada DPRD Kabupaten/Kota yang ditunjuk oleh Gubernur. Konsekuensinya, pemilukada Gubernur menggunakan sistem absolut majority dimana pemenang sedikitnya mendapatkan 50\% suara. Di daerah lain, kecuali Yogyakarta, cukup mendapatkan lebih dari 30\% suara.

Ketiga, alasan sejarah dan budaya. Daerah Istimewa Yogyakarta mendapatkan perlakuan istimewa mengingat sejarahnya di masa revolusi dan perebutan kemerdekaan. Perlakuan ini terlihat dari penetapan Gubernur dan Wakil Gubernur di DIY yang dilakukan oleh DPRD. Gubernur DIY adalah Sultan yang bertahta dan Wakil Gubernur DIY adalah Pakualam yang bertahta. Penentuan Sultan dan Pakualam diserahkan kepada institusi keratin/pakualam masing-masing. Kedua pemimpin ini tidak boleh bergabung dengan partai politik. Pada level kabupaten/kota tetap sama dengan daerah lainnya.

10 Nurcholis,"Pemerintaha Lokal Asimetris dan Model Pengawasannya"dalam Dini Suryani,Pengawasan Pengelolaan Dana Otsus dan Dana Istimewa dalam Desentralisasi Asimetris, Jurnal Administrasi Publik,Edisi No 2 Vol.14,2013,hlm 265

${ }^{11}$ Bayu Dardias Kurniadi,"Desentralisasi Asimetris di Indonesia”, Makalah Yang Disampaikan Pada Seminar di LAN Jatinangor tanggal 26 November 2012,hlm 8 
Keempat, alasan perbatasan. Menurut Tim JPP (JPP-UGM 2010), perbatasan perlu mendapatkan perlakuan khusus mengingat perannya sebagai batas dengan negara tetangga. Daerah perbatasan memegang fungsi penting karena kompleksitas masalah yang dihadapi. Daerah perbatasan harus diperlakukan sebagai halaman depan dan bukan halaman belakang RI. Perlakukan daerah perbatasan, misalnya di Kalimatan Barat hendaknya berbeda, misalnya dengan mewajibkan gubernurnya berasal dari kalangan militer karena potensi pelintas batas yang tinggi disamping penguatan infratruktur dan pelayanan pendidikan dan kesehatan. Detail tentang asimetrisme perbatasan masih membutuhkan kajian lebih lanjut.

Kelima, pusat pengembangan ekonomi. Daerah yang secara geografis memiliki peluang untuk menjadi daerah khusus ekonomi seharusnya dikembangkan agar memiliki daya saing ekonomi tinggi. Daerah seperti Batam dapat dikembangkan dan dibentuk untuk menyaingi Singapura. Alokasi kekhususan misalnya menyangkut bea masuk dan pengembangan infrastruktur pengembangan ekonomi seperti pelabuhan dan tata sistem pelabuhan. Pelabuhan terbesar di Indonesia saat ini, Tanjung Priok di Jakarta lebih untuk memenuhi kebutuhan dalam negeri karena posisi geografisnya. Jika Batam dikembangkan dengan pelabuhan modern dengan sistem yang baik, tidak mustahil mampu mengambil potensi pelabuhan Singapura yang memiliki keterbatasan ruang. Detail tentang asimetrisme pengembangan ekonomi masih membutuhkan kajian lebih lanjut.

Itulah kelima alasan bagi munculnya desentralisasi asimetris di Indonesia pasca reformasi. Selain itu, dalam pertemuan Tim JPP dengan Dirjen Otda Prof. Djohermansyah Djohan pada saat diseminasi hasil kajian Aceh dan Papua, sempat muncul wacana agar Undang Undang yang mengatur tentang pemekaran daerah di tingkat provinsi dapat memasukkan asas desentralisasi asimetris yang menambah daya jual provinsi baru. Artinya, rencana Provinsi baru seperti Kalimantan Utara harus sudah memasukkan pengaturan asimetris terkait dengan fungsi perbatasan. Pemekaran provinsi tidak hanya sama dengan daerah lain di Indonesia tetapi sudah harus memperhatikan kekhususan yang dimiliki menyangkut wewenang, lembaga, keuangan dan kontrol yang berbeda sehingga tidak perlu membuat dua kali undang undang. ${ }^{12}$ Model pengelolaan desentralisasi yang ideal meliputi pertama, Aspek kewenanangan asimetris dalam pengelolaan kewenangan asimetris meliputi kekekuasaan dalam pengelolaan kewenangan yang diberikan oleh pusat kepada pemerintah daerah otsus dan istimewa, khususnya dalam bidang politik, ekonomi, sosial, budaya, fiscal dan administrasi kecuali urusan yang menjadi kewenangan pemerintah pusat. Di dalam urusan penyelenggaraan pemerintahan, pemerintah dapat melaksanakan sendiri, menyerahkan sebagian kewenangan kepada pemerintah daerah otsus/istimewa. Hal ini diatur dalam undang-undang otsus Aceh, undang-undang otsus Papua dan Papua Barat, dan undang-undang istimewa Daerah Istimewa Yogyakarta.

\section{B. Pengaturan Kewenangan Provinsi Kepulauan Dalam Pengelolaan Sumber Daya Alam Yang Dapat Mewujudkan Kesejahteraan Masyarakat.}

Sebagai negara yang terletak pada posisi strategis di garis khatulistiwa, Indonesia memiliki sumber daya alam yang melimpah, terbesar dan tersebar di seluruh wilayah

\footnotetext{
${ }^{12}$ Ibid.,hlm 11
} 
nusantara, tidak hanya di daratan, tetapi juga di lautan. Kekayaan alam ini merupakan anugerah Tuhan, yang dilimpahkan kepada seluruh bangsa Indonesia, untuk dipergunakan bagi sebesar-besarnya kemakmuran rakyat. Sumber daya alam tersebut pada kekuasaan tertinggi berada di tangan negara, dan negaralah yang akan mengatur peruntukan dan penggunaanya bagi kesejahteraan masyarakat. Pemerintah hanyalah sebagai personifikasi rakyat yang memiliki kewenangan mengelola sumber daya alam, namun pemilik sesungguhnya adalah rakat Indonesia. Hal ini tercermin di dalam ketentuan Pasal 33 ayat (3) UUD 1945. Berdasarkan ketentuan Pasal 1 ayat (1) Undang Undang Dasar 1945, Negara Indonesia ialah negara kesatuan yang berbentuk republik", berarti di dalam negara hanya terdapat satu kekuasaan, yaitu kekuasaan negara Republik Indonesia". Sistem pemerintahan sentralistik telah dipilih Indonesia selama bertahuntahun, kekuasaan negara terpusat pada kekuaatan pemerintah pusat di bawah pimpinan Presiden. Sistem pemerintahan sentralistik sesungguhnya tidak sesuai dengan karakter Indonesia sebagai negara kepulauan yang memiliki aneka keragaman budaya, agama, sosial, ras, suku, dan adat istiadat, serta potensi sumber daya alam yang masingmasing daerah memiliki karakter yang berbeda-beda. Seharusnya daerah memiliki kewenangan untuk mengelola sumber daya alam yang dimiliki untuk dimanfaatkan bagi kesejahteraan masyarakatnya. Sesungguhnya apabila daerah diberikan kewenangan yang luas untuk mengelola sumber daya alam sebagai sumber pembiayaan rumah tangga daerahnya akan dapat merangsang inisiatif dan kreatifitas daerah untuk terus berupaya menggali seluruh potensi sumber daya alam yang dimilikinya secara maksimal. Semangat tersebut selaras dengan tujuan dari desentralisasi dan otonomi daerah, namun bukan berarti pemerintah daerah dapat bertindak semaunya sendiri, tanpa memperhitungkan dampak dari kebijakannya terhadap keselamatan dan keseimbangan lingkungan hidup secara nasional. Pembatasan-pembatasan terhadap kewenangan daerah otonom tetap harus dilakukan melalui produk hukum perundang-undangan, sebab bagaimanapun juga luasnya otonomi yang diberikan oleh UUD 1945 beserta peraturan pelaksanaanya. ${ }^{13}$

Desentralisasi pengelolaan sumber daya alam oleh Pemerintah Pusat kepada Pemerintah Daerah, memang tidak sesederhana dalam teori, karena menyangkut kepentingan strategis dan tanggung jawab pengendalian kebijakan pembangunan secara nasional. Sinkronisasi dan harmonisasi kewenangan pengelolaan sumber daya alam mutlak dilakukan untuk mengatasi kerancuan landasan hukum pengelolaan sumber daya alam di daerah, serta perlu menempuh kebijakan-kebijakan strategis, guna mencegah timbulnya konflik norma yang berpotensi menimbulkan ketidakpastian hukum, yang berujung pada ketidkadikan masyarakat. Pemberian kewenangan seluas-luasnya kepada Pemerintah Daerah untuk menggali, mengelola dan memanfaatkan sumber daya alam yang dimiliki bagi kesejahteraan masyarakat di daerah, merupakan amanat konstitusi yang secara normatif wajib dilaksanakan secara sungguh-sungguh. Namun dalam pelaksanaanya terjadi berbagai penyimpangan dan penyalahgunaan wewenang oleh penyelenggara pemerintahan di daerah, tidak dapat dijadikan dalil untuk menafikan amanat konstitusi. Klausul yang menyatakan "pemerintah daerah menjalankan otonomi seluas-luasnya", merupakan penegasan konstitusional yang bersifat imperative imperatif, sehingga tidak ada alasan hukum yang dapat dijadikan landasan berpijak untuk tidak melaksanakannya. Namun yang perlu dilakukan adalah pembentukan

13 Slamet Suhartono,'Desentralisasi Pengelolaan Sumber Daya Alam Untuk Mewujudkan Kesejahteraan masyarakat,Jurnal Ilmu Hukum,Edisi No 18 Vol.9,2013,hlm 110 
perangkat hukum yang secara efektif dapat mencegah kemungkinan terjadinya penyalahgunaan wewenang, tanpa harus mengingkari tujuan essensial dari desentralisasi dan otonomi daerah. ${ }^{14}$

Konsep pengelolaan sumber daya alam di daerah juga bertujuan untuk mewujudkan kesejahteraan masyarakat di daerah, tentunya tidak dapat dilepaskan dari konsep negara kesatuan Republik Indonesia. Berdasarkan konsep negara kesatuan ini, maka kiranya pemahaman konsep wewenang pengelolaan sumber daya alam tidak harus dimaknai secara luas seluas-luasnya, namun harus tetap dipadukan dengan kepentingan nasional. Konsep wewenang pengelolaan sumber daya alam di daerah harus dikembalikan pada prinsip kekuasaan tertinggi atas tanah berada di bawah kekuasaan negara. Pasal 33 ayat (3), kiranya telah memberikan landasan yang jelas bagi kekuasaan tertinggi negara atas bumi, air, dan ruang angkasa, termasuk kekayaan alam yang terkandung di dalamnya. Pemberian kewenangan yang seluas-luasnya kepada daerah dalam mengelola sumber daya alam yang dimiliki merupakan bentuk perlawanan dari konsep menguasai negara atas sumber daya alam yang merupakan kekayaan negara.

Secara teoritik desentralisasi dan otonomi pengelolaan sumber daya alam kepada daerah memang secara lamat laun dapat mengurangi ketergantungan daerah terhadap pemerintah pusat, bahkan dapat mengarah pada kemandirian daerah dalam membiayai kebutuhan rumah tangga daerahnya sendiri. Namun harus diakui bahwa desentralisasi ini menyisakan permasalahan yang sangat krusial, sebab tidak semua daerah memiliki sumber daya alam yang mencukupi untuk dikelola guna memenuhi kebutuhan daerah, tidak sedikit daerah yang meskin sumber daya alam. Di samping itu, terdapat daerah yang secara ekonomi memiliki potensi sumber daya alam yang melimpah, tetapi tidak memilki sumber daya manusia yang mencukupi, juga sarana dan prasarana yang sangat minim, sehingga akan menghambat pengelolaan sumber daya alam tersebut. Sementara itu untuk membangun sarana dan prasarana tersebut memerlukan dana yang tidak sedikit, oleh karena itu pemerintah daerah dituntut pandai mencari celah yang memungkinkan dapat membantu mengatasi masalah tersebut. ${ }^{15}$ Kewenangan provinsi kepulauan dalam pengelolaan sumber daya alam dijabarkan sebagai berikut: Pertama, wilayah laut daerah kepulauan, mempunyai kewenangan yaitu batas daerah kepulauan di wilayah laut merupakan ruang pelaksanaan kewenangan daerah kepulauan dalam rangka pengelolaan dan pemanfaatan sumberdaya alam di laut; batas kewenangan daerah provinsi kepulauan di wilayah laut sejauh 12 (dua belas) mi laut diukur dari garis yang meng- hubungkan titik-titik terluar dari pulau-pulau atau karang terluar suatu daerah kepulauan ke arah laut lepas atau perairan kepulauan; apa- bila wilayah laut antara 2 (dua) provinsi kurang dari 24 (dua puluh empat) mil laut, kewenang- an untuk mengelola dan memanfaatkan sum- berdaya alam di wilayah laut dibagi sama jaraknya atau diukur sesuai prinsip garis tengah dari wilayah antar dua provinsi tersebut. Batas kewenangan daerah kabupaten/kota kepulauan di wilayah laut sejauh maksimal 6 (enam) mil laut diukur dari garis yang menghubungkan titik-titik terluar dari pulau dan/atau karang terluar dari daerah kabupaten/kota kepulauan, yang ditetapkan dalam Peraturan Daerah Pro- vinsi; Dalam wilayah kewenangan daerah kabu- paten/kota kepulauan di laut, dapat ditetapkan wilayah kewenangan kesatuan masyarakat

${ }^{14}$ Oentarto, Menggagas Format Otonomi Daerah Masa Depan,Jakarta,Samitra Media Home, 2004, hlm. 17

15 Syaukani, Afan Gafar, M. Ryas Rasyid, Otonomi Daerah Dalam Negara Kesatuan, Yogyakarta,Pustaka Pelajar,2002, hlm., 68 
hukum adat yang tidak boleh kurang dari 1,5 (satu koma lima) mil laut diukur dari garis air rendah kearah laut lepas atau perairan kepu- lauan dan diatur dalam Peraturan Daerah Kabu- paten/Kota; Penetapan batas kewenangan dae- rah di wilayah laut, tetap menghormati hak-hak penangkapan ikan yang secara tradisional telah berlangsung. Kedua, Kewenangan Daerah Kepulauan di laut yang terdiri dari daerah kepulauan diberikan kewenangan untuk mengelola dan memanfaatkan sumberdaya alam di wilayah laut, baik di bawah dasar dan atau di dasar laut dan atau perairan di atasnya; daerah Kepulauan mendapatkan bagi hasil atas pengelolaan sumber- daya alam di laut, baik di bawah dasar dan atau di dasar laut dan atau perairan di atasnya sesuai dengan peraturan perundang-undangan; Kewenangan daerah kepulauan untuk melakukan pengelolaan dan pemanfaatan sumberdaya alam di laut meliputi: eksplorasi, eksploitasi, konservasi, pengelolaan dan pemanfaatan ke- kayaan laut; pengaturan administratif; peng- aturan tata ruang; penegakan hukum terhadap peraturan yang dikeluarkan oleh daerah atau yang dilimpahkan kewenangannya oleh Peme- rintah; ikut serta dalam pemeliharaan keaman- an; dan ikut serta dalam pertahanan dan keamanan Negara; selain itu, Pemerintah dan pemerintahan daerah melakukan kadasterisasi wilayah laut untuk mewujudkan kepastian hukum dalam pengelolaan dan pemanfaatan sumberdaya alam di laut.

\section{SIMPULAN}

Desentralisasi asimetris dalam pengaturan kewenangan provinsi kepulauan merupakan hal penting untuk dipertimbangkan sebab, faktor luas wilayah perairan (lautan) sebagai satu kesatuan wilayah, dapat berdampak pada terhambatnya proses pembangunan dan pelayanan kepada masyarakat di provinsi kepulauan. Oleh karena itu, untuk menata kehidupan ber- masyarakat di wilayah geografis yang wilayah lautannya lebih besar dari daratan, secara politis diperlukan adanya legitimasi hukum mengenai kesatuan wilayah dan perlakuan khusus pada provinsi kepulauan. Kewenangan provinsi kepulauan dalam Pengelolaan sumber daya alam diartikan sebagai pembangunan yang mengacu pada kebutuhan masyarakat, memanfaatkan sumber daya alam yang ada dan dapat diakses oleh masyarakat. Sesungguhnya apabila provisni kepulauan diberikan kewenangan yang luas untuk mengelola sumber daya alam sebagai sumber pembiayaan rumah tangga daerahnya akan dapat merangsang inisiatif dan kreatifitas daerah untuk terus berupaya menggali seluruh potensi sumber daya alam yang dimilikinya secara maksimal. Semangat tersebut selaras dengan semangat desentralisasi asimentris.

\section{DAFTAR PUSTAKA}

Asshiddiqie, Jimly. Hukum Tata Negara dan Pilar-Pilar Demokrasi, Jakarta:Sinar Grafika, 2015

-,Konstitusi Keadilan Sosial: Serial Gagasan Konstitusi Sosial Negara Kesejahteraan Sosial Indonesia, Jakarta: Kompas, 2018.

Basyah, Syahran. Perlindungan Hukum Terhadap Tindak Administrasi Negara, (Bandung: Alumni, 1992.

Huda, Ni'matul. Hukum Tata Negara Indonesia (Edisi Revisi), Jakarta: RajaGrafindo, 2014.

-------, Desentralisasi Asimetris Dalam NKRI, Bandung: Nusa Media, 2014.

Jaweng, Robert Endi. Kritik terhadap Desentralisasi Asimetris di Indonesia, Jurnal Analisis CSIS, Volume 40, Nomor 2 Juni 2011 
Kurniadi, Bayu D. Desentralisasi Asimetris di Indonesia, makalah seminar di LAN Jatinangor tanggal 26 November

Kaho, Josep Riwu. Mekanime Pengontrolan Dalam Hubungan Pemerintah Pusat Dan Daerah, Jakarta: Bina Aksara, 1996

Kotan Y. Stefanus,'Daerah Kepulauan Sebagai Satuan Pemerintahan Daerah Yang Bersifat Khusus,Jurnal Dinamika Ilmu Hukum,Edisi No.1 Vol.11,2011,

Mahmud, Peter. Penelitian Hukum, Jakarta: Kencana, Prenada Media Group, 2007.

--------, Penelitian Hukum (edisi revisi), Jakarta: Kencana, Prenada Media Group, 2005.

Manan, Bagir. Politik Perundang-undangan Dalam Rangka Mengantisipasi Liberalisasi Otonomi, Bandar Lampung: FH-UNILA, 1996

Nurcholis,"Pemerintaha Lokal Asimetris dan Model Pengawasannya"dalam Dini Suryani,Pengawasan Pengelolaan Dana Otsus dan Dana Istimewa dalam Desentralisasi Asimetris,Jurnal Administrasi Publik,Edisi No 2 Vol.14,2013

Nyimas Latifah Letty Azis,Model Desentralisasi Asimetris Dalam NKRI,Jakarta, Yayasan Pustaka Obor Indonesia,2020

Oentarto, Menggagas Format Otonomi Daerah Masa Depan,Jakarta,Samitra Media Home, 2004

Syaukani, Afan Gafar, M. Ryas Rasyid, Otonomi Daerah Dalam Negara Kesatuan, Yogyakarta,Pustaka Pelajar,2002

Suhartono,"Slamet Desentralisasi Pengelolaan Sumber Daya Alam Untuk Mewujudkan Kesejahteraan masyarakat,Jurnal Ilmu Hukum,Edisi No 18 Vol.9,2013

Tauda Gunawan A.,'Desain Desentralisasi Asimetris Dalam Sistem Ketatanegaraan Indonesia",Jurnal Admnistrative Law dan Governance Law,Edisi No 4 Vol. I,2018

Utrecht, E. Pengantar Hukum Administrasi Negara, Surabaya: Pustaka Tinta Mas, 1986.

Wasistiono Sadu,'Kajian Hubungan antara Pemerintah Pusat Dengan Pemerintah Daerah (Tinjauan dari Sudut Pandang Manajemen Pemerintahan)”,Jurnal Administrasi Pemerintahan,Edisi No.1 Vol.1,2004

Yoseph M. Laynurak,"Analisis Model Optimalisasi Sumber Daya Laut Pantai Terhadap Kesejahteraan Nelayan di Kabupaten Belu NTT,"Jurnal Litbang NTT Floba Mora, Edisi No 01 Vol.1,2009

\section{Peraturan Perundang-undangan}

Undang-Undang Dasar Negara Republik Indonesia Tahun1945

Undang-Undang Nomor 23 Tahun 2014 tentang Pemerintahan Daerah

Keputusan Presiden Nomor 06 Tahun 2017 tentang Penetapan Pulau-Pulau Kecil Terluar

Website

2012,http://bdardias.staff.ugm.ac.id/wp-content/uploads/2008/06/Desentralisasi Asimetris-di-Indonesia-LAN-Bdg-26112012.pdf 